\title{
REPORT OF THE PRESIDENT ${ }^{1}$
}

The report of the Secretary-Manager covers fully the affairs of the Institute and makes a President's report almost unnecessary.

During the past year our Institute has added many new members and total membership now stands at 1,913. Much of the credit for this increase must be given to our Secretary-Manager who has worked so hard for the Institute and for the cause of forestry in general.

Mr. Dosne has now completed his first full year in office and the work that he has been able to accomplish fully justifies his appointment.

It was with sincere regret that we received the resignation of Mr. Kingsley Harris as editor of The Forestry Chronicle. Under his able guidance the Chronicle has maintained a high standard of excellence, and the Institute is deeply in his debt.

The Committee composed of K. G. Fensom, D. V. Love, and Dr. R. E. Balch, entrusted with the task of selecting a new Editor, was fortunate in obtaining the services of Dr. Harry Smith, Faculty of Forestry, University of British Columbia, as successor to Mr. Harris.

Throughout the year, Committee Chairmen G. R. Morrison, A. L. Best, J. F. Flowers, G. A. Sinclair, R. G. Ray, Dean J. W. B. Sisam, Professor S. Pringle, R. J. Bourchier and R. K. Allen, carried out their several duties in a most commendable manner, and the thanks of the Institute are due to them and to their committee members.

The Institute is also greatly indebted to Mr. Roy Campbell for his assistance with the By-laws of the Institute as approved by the Under-Secretary of State of Canada in August 1959.

At this time I would like to offer my congratulations to Mr. Hugh Hodgins, President elect, and to the other newly elected officers and directors.

With the 51st Annual Meeting held here in Prince George, it is most fitting that our new President is from the wonderful Province of British Columbia. In handing over the chair to him, I wish to extend best wishes for a successful term of office.

In conclusion I would like to thank the members of the Canadian Institute of Forestry for permitting me to serve as President for the past two years. I have deeply appreciated the honor, and I hope in return I will be able to contribute to the success of the Institute in some small measure in years to come. Presented by the President, Dr. G. W. I. Creighton, at the 1959 Annual Meeting of the
Canadian Institute of Forestry at Prince George, British Columbia. 